\title{
Hydrogen Production for Solar Energy Storage
}

\author{
P. Moldrik and Z. Hradilek \\ Department of Electrical Power Engineering \\ FEI, VSB - Technical University of Ostrava \\ 17. listopadu 15, 70833 Ostrava - Poruba (Czech Republic) \\ Phone/Fax number:+420 596919597, e-mail: petr.moldrik@vsb.cz, zdenek.hradilek@vsb.cz
}

\begin{abstract}
Using solar energy in photovoltaic power plants is an important method of electricity generation from renewable sources. Its potential is vast and technically easy to utilise. At present, photovoltaic power plants are the fastest-growing renewable energy source (RES) in the Czech Republic. Their installed capacity reached $1390 \mathrm{MWp}$ (December 2010). Only in the last two years more than $1300 \mathrm{MWp}$ was put in operation. This rapid development of photovoltaic sources is having a negative effect on the electric power system control. One option for mitigating this effect is to store the energy generated by photovoltaic in times of excess power in the grid and supply it to the grid when required, i.e., during peak periods of the daily load curve. There are numerous different storage technologies. The hydrogen system can be used to provide for storage of electric power in large amounts as well. This paper describes the state-of-the-art in the field of our research into solar energy storage in the Technical University of Ostrava.
\end{abstract}

\section{Key words}

\section{Hydrogen, Photovoltaic, Solar, Energy Storage}

\section{PV Power Plants in the Czech Republic}

The current situation in the Czech Republic, with respect to the renewable energy sources, is dramatic mainly due to the number of applications for connection of new photovoltaic (PV) power plants into the electric power system. As of $1^{\text {st }}$ December 2010 the electric power system admitted new plants with the total output equal to 1393,86 MWp. Over the year 2009, these plants produced approximately $90 \mathrm{GWh}$ of electric power. [1] That was the year bringing the most significant increase in number of the PV plants constructed, which is documented by the graph in Figure 1.

\section{A. Impact on Electric Power System}

If there is a new source (power plant) linked directly into a $110 \mathrm{kV}$ centre or into a MV centre switch house, its production will be only projected into the superior network. However, if the MV switch house is linked to the source with an uncontrollable unit with fairly high fluctuation, e.g. photovoltaic power plant, whereas the load on such output is comparable with the output produced by the source, the network voltage might be difficult to control. Branching on $\mathrm{MV} / \mathrm{LV}$ transformers are fixed, with no option for automatic control. Any fluctuation of output from the source, which is obviously not relevant on demands from power consumers and their electric power demand diagram, may cause problems due to the failure to maintain the allowed threshold of voltage within MV and LV networks. The quality of electric po-

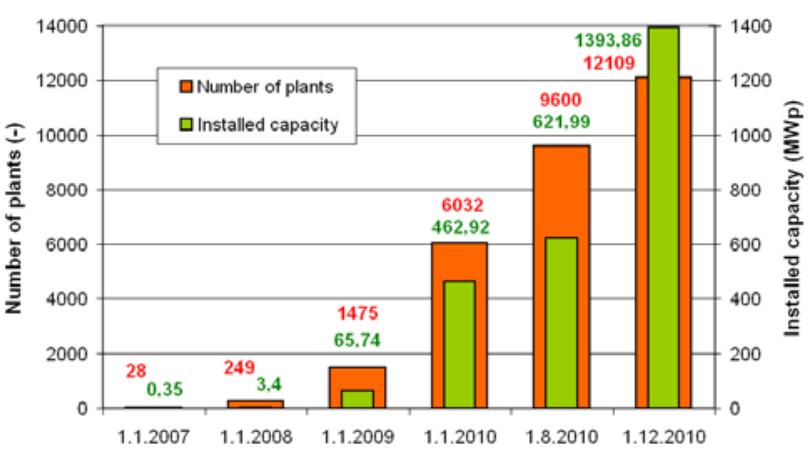

Fig. 1. The progress of installed capacity and the number of PV power plants operated in the Czech Republic [1]

wer supply to end users could then show deterioration and failure to adhere to the required parameters. There have been no significant requirements imposed in relation with compulsory control over these sources and the only threshold values defined refer to the limit values concerning parameter changes, which cannot be interfered with by any output values of the generators linked to distribution channels. [2]

\section{B. Comparison of PV Plants to Other RES}

Table I. shows benchmark of particular renewable energy source (RES) parameters with respect to the average period associated with utilisation of their maximum installed capacity throughout the year. The values in this table prove that PV plants are the least effective units compared to other RES in the Czech Republic.

Table I. - Comparison of PV plants to other RES [2]

\begin{tabular}{|c|c|c|c|c|c|}
\hline RES: & SHPS & WPP & Biomass & Biogas & PPP \\
\hline $\begin{array}{c}\text { Average period } \\
\text { of utilisation of } \\
\text { the maximum } \\
\text { of unit's } \\
\text { installed } \\
\text { capacity }\end{array}$ & $\begin{array}{c}4700 \\
\mathrm{~h} / \mathrm{yr}\end{array}$ & $\begin{array}{c}1900 \\
\mathrm{~h} / \mathrm{yr}\end{array}$ & $\begin{array}{c}5000 \\
\mathrm{~h} / \mathrm{yr}\end{array}$ & $\begin{array}{c}7500 \\
\mathrm{~h} / \mathrm{yr}\end{array}$ & $\begin{array}{c}990 \\
\mathrm{~h} / \mathrm{yr}\end{array}$ \\
\cline { 2 - 6 } & $54 \%$ & $22 \%$ & $57 \%$ & $86 \%$ & $11 \%$ \\
\hline
\end{tabular}

Share of particular RES on the total amount of electric power produced in Czech Republic is shown below [3]:

- SHPS (Small hydroelectric power station): 7,3\%

- WPP (Wind power plant): 1,7\%

- Biomass: 70,5\%

- Biogas: $4,6 \%$

- PPP (Photovoltaic power plant): 1,9\%

- Others (Bio-fuell for transport, Heat pump): 14\% 


\section{RES in the Research Laboratory}

The figure 2 shows twelve polycrystalline photovoltaic panels (Schott Poly 165 type) providing a power output of $1980 \mathrm{Wp}$, installed on the roof of our research laboratory in the Technical University of Ostrava. These PV panels constitute a renewable source of energy (RES) to form part of the investigated storage system using hydrogen technology devices. The parameters of these PV panels are shown in Table II.

A photovoltaic panel is composed of PV cells, which may be composed of semiconductor or organic elements converting the energy of light into electricity. Using silicon PV panels, approximately $17 \%$ of the energy of the impacting radiation can be converted into electricity. This should be up to $25 \%$, using the organic PV panels currently in development. The electrical output is the function of the total surface and efficiency of the PV cells. A monocrystalline cell with a surface of $100 \mathrm{~cm}^{2}$ is capable of supplying a load with approximately a $3 \mathrm{~A}$ current at $0.5 \mathrm{~V}$, providing an output of approximately $1.5 \mathrm{Wp} .[4]$

The serial installation of cells yields higher voltage; parallel installation, higher current. The same applies to PV panels composed of such cells. The amount of electricity a power plant composed of PV panels generates, follows from the intensity of the solar radiation. PV panels can generate electricity even under diffuse light, when the sky is cloudy. The panels of a PV power plant with an installed capacity of $1 \mathrm{kWp}$ occupy some $8 \mathrm{~m}^{2}$ of surface. This surface can generate approximately $1 \mathrm{MWh}$ of electricity per year. [5]

Table II. - The parameters of PV panels installed

\begin{tabular}{|l|c|}
\hline Nominal power & $165 \mathrm{Wp}$ \\
\hline Voltage at nominal power & $35,1 \mathrm{~V}$ \\
\hline Current at nominal power & $4,7 \mathrm{~A}$ \\
\hline Open - circuit voltage & $43,6 \mathrm{~V}$ \\
\hline Short - circuit current & $5,27 \mathrm{~A}$ \\
\hline Module efficiency level & $12,6 \%$ \\
\hline
\end{tabular}

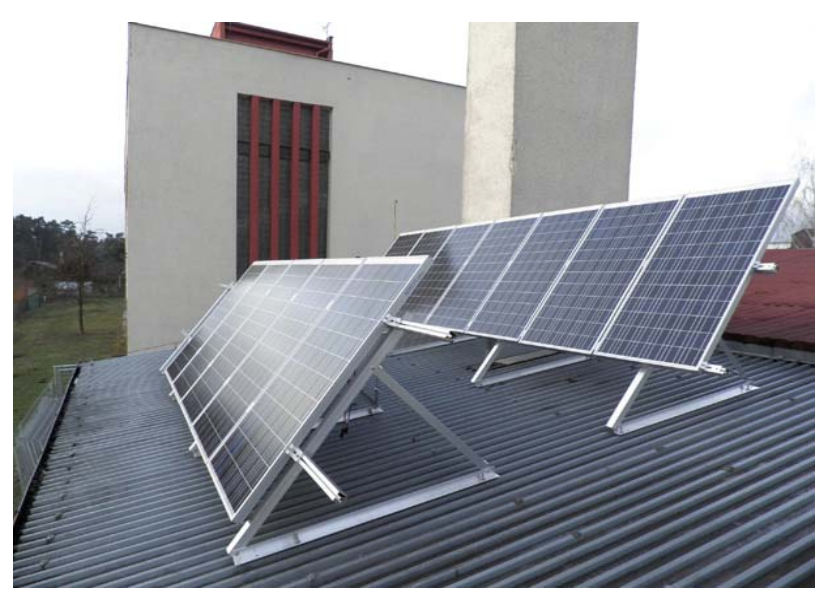

Fig.2. PV panels on the roof of research laboratory

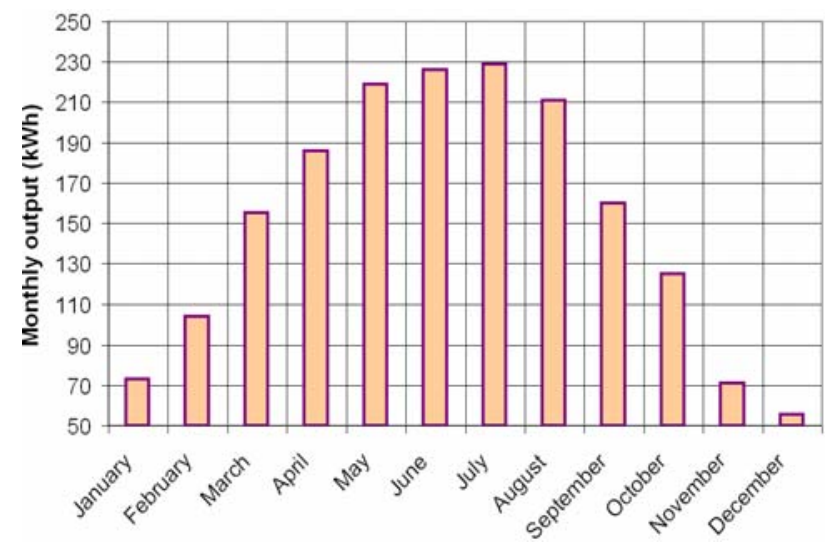

Fig.3. Estimation of generated electrical energy from PV panels

Figure 3 shows the yearly estimated volume of electricity generated from the above mentioned PV panels based on the defined configuration - PV panels inclination and orientation. It shows volumes of monthly production. The total yearly electricity generation is approx. $1800 \mathrm{kWh}$ at the yearly sum of solar radiation of approx. 1130 $\mathrm{kWh} / \mathrm{m}^{2}$. [6]

\section{Research into Solar Energy Storage Using Hydrogen PEM Technology}

The storage system based on the hydrogen PEM (Proton Exchange Membrane) technology seems to be very prospective with regard to cooperation with the photovoltaic power plants. There is currently a research focused on this technology in progress, together with examination of its practical application. This research also involves our laboratory, concerned with sophisticated experimental laboratory implementation of the model hydrogen system for storage of electric energy produced by photovoltaic panels. A simplified schematic of the energy storage from PV panels in hydrogen and its subsequent use in fuel cells is shown in Figure 4.

The figure 5 shows our workstation with low-temperature PEM electrolyzer and two PEM fuel cells modules. The hydrogen generator (Hogen GC600) produces a continuous stream of pressurized hydrogen gas $(600 \mathrm{cc} / \mathrm{min})$ and

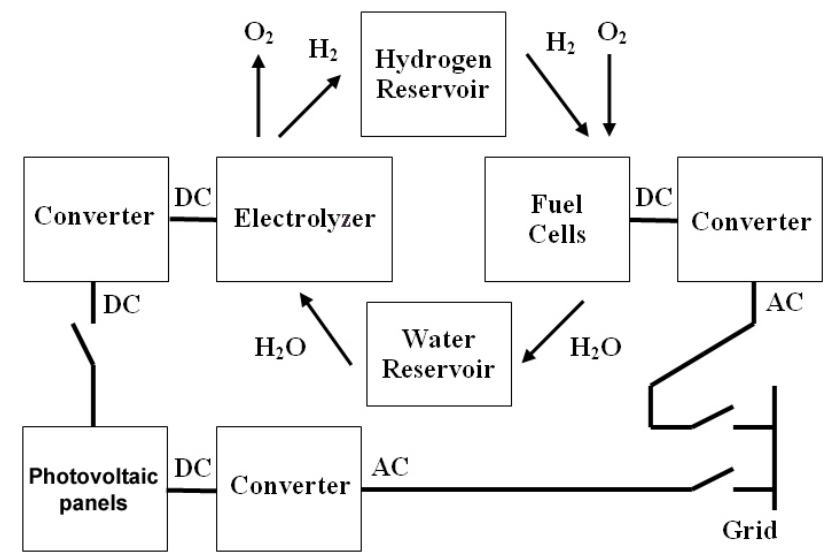

Fig. 4. The hydrogen storage system schematic 


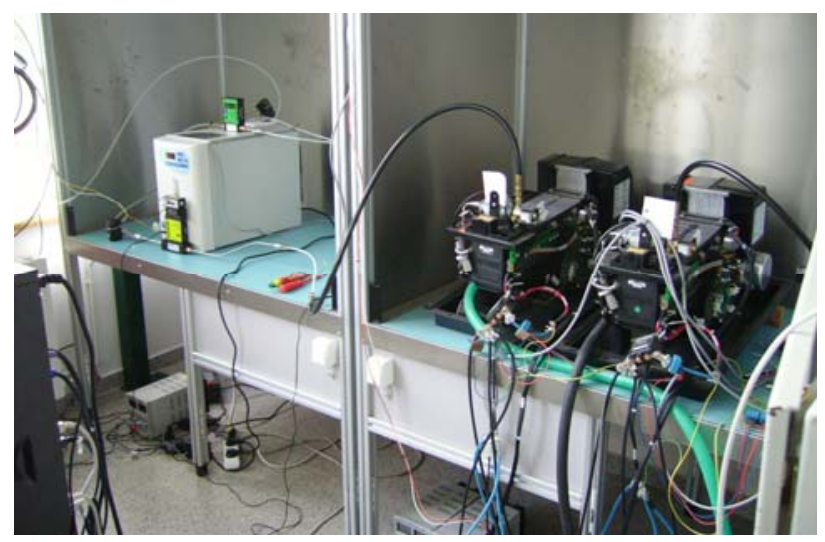

Fig. 5. PEM electrolyzer and two PEM fuel cells modules

automatically maintains a user-selected downstream pressure (up to 13,8 bar). The nominal power output of each fuel cells module (Ballard Nexa module) is $1200 \mathrm{~W}$ and the nominal voltage is $26 \mathrm{~V}$. The module comprises a serial installation of fuel cells, a fan, a compressor, control electronics, and other auxiliary devices. The power output from the modules can be supplied to the LV grid via two one-phase inverters with a nominal output power of $1100 \mathrm{~W}$. Laboratory is equipped with hydrogen and nitrogen (safety gas) distribution network. Demineralized water, like the input medium for electrolyzer is prepared in osmotic filtration unit.

The electrolyser, supplied with the electricity generated by the PV panels, decomposes demineralised water into hydrogen and oxygen by conducting it through the power current. The pressurised hydrogen is stored in a vessel for future use. The oxygen created by the water decomposition is either released into the atmosphere or stored in a separate vessel. The electricity from the fuel cells is supplied during periods of a lack of electricity - the peak periods of the daily load curve. The fuel cells are fed with the stored hydrogen and oxygen from the air or the vessel. Using the pure oxygen from the vessel increases the fuel cells efficiency, thus the entire system efficiency increases, compared to using air as the oxidant. [7]

\section{Hydrogen Based Devices}

The electrolyser and the fuel cell modules are the crucial components of hydrogen storage system. It is they that influence the resulting technical parameters of this system. The capacity of both devices is directly related to the surface of the electrodes, which constitute most of the total cost. The total amount of energy stored depends on the hydrogen storage vessel content and the size of the power input from RES, i.e., the photovoltaic power plant.

The storage system described has been subjected to testing of the electrolyzer and the fuel cells modules with optimisation of their operation. We have resolved their co-operation with the inverters (Sunny Boy type), via which they can deliver the electricity generated from hydrogen into the grid. The research also focuses on monitoring storage system outages during its operation. The reliability indicators will be defined on this basis. [8]

The following two chapters deal with surveyed parameters of PEM type electrolyzers and fuel cells, that are important for their optimum operation in hydrogen storage system.

\section{A. PEM Electrolyzer}

The electrolyzer is composed of electrodes and a gas separator, which separates the hydrogen produced from the oxygen. Instead of aqueous electrolyte, this type of electrolyzers works with sulfonated tetrafluoroethylene (Nafion). Water is the coolant as well as the reactant. The amount of hydrogen produced depends on the flow density. PEM electrolyzer can operate at much higher current densities than alkaline electrolyzer $\left(1-2 \mathrm{~A} / \mathrm{cm}^{2}\right)$ and works at $80-90{ }^{\circ} \mathrm{C}$. PEM electrolyzers produce hydrogen with very high purity (up to 99.999), which may be used in a PEM fuel cells because the Platinium catalyst has little tolerance to sulphur compounds or carbon monoxide, and decomposition of the membrane is induced by impurities. [9]
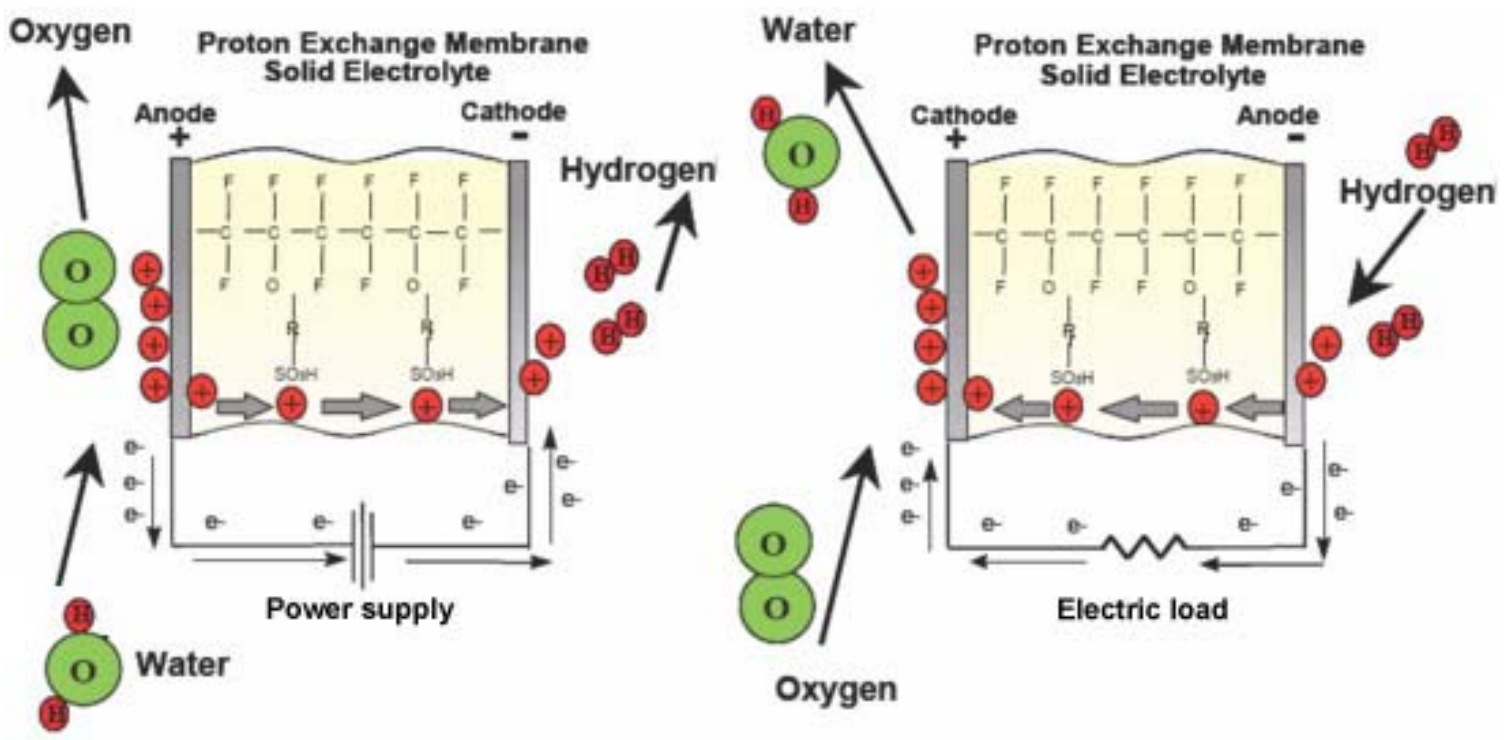

Fig. 6. Simplified diagram of PEM electrolyzer (left) and PEM fuel cell (right) 
Figure 6 shows PEM electrolyzer principle. These electrolyzers provide for the chemical reaction listed below:

- Anode: $2 \mathrm{H}_{2} \mathrm{O} \Rightarrow 4 \mathrm{H}^{+}+4 \mathrm{e}^{-}+\mathrm{O}_{2}$

- Cathode: $4 \mathrm{H}^{+}+4 \mathrm{e}^{-} \Rightarrow 2 \mathrm{H}_{2}$

- Overall reaction: $2 \mathrm{H}_{2} \mathrm{O} \Rightarrow 2 \mathrm{H}_{2}+\mathrm{O}_{2}$

- Water Consumption:

Theoretically from one litre of water $1,24 \mathrm{Nm}^{3}$ of hydrogen can be produced. Actual water consumption is about $25 \%$ higher, since both gases leave the electrolyzer wet, and some water is lost from the system due to oxygen exhaust and periodic hydrogen purge. This is particularly important for the systems that are supposed to work in a closed loop with a fuel cell. If the fuel cell uses air instead of pure oxygen, some water is lost there due to air exhaust from the fuel cell. [10]

\section{- Electrolyzer Efficiency:}

The efficiency of an electrolyzer is inversely proportional to the cell potential, which in turn is determined by the current density, which in turn directly corresponds to the rate of hydrogen production per unit of electrode active area. Typical industrial electrolyzers have electricity consumption between 4,5 and $6,0 \mathrm{kWh} / \mathrm{Nm}^{3}$, corresponding to the energetic efficiency of $65-80 \%$. [10]

The electrolyzer efficiency is therefore:

$$
\eta_{E L}=\frac{1,482}{V_{\text {cell }}} \cdot \frac{i-i_{\text {loss }}}{i} \cdot \frac{\eta_{D C}}{1+\xi}
$$

where $V_{\text {cell }}$ is the individual (average) cell potential (V), $i$ is the operating current density $\left(\mathrm{A} / \mathrm{cm}^{2}\right), i_{\text {loss }}$ is the internal current and hydrogen loss $\left(\mathrm{A} / \mathrm{cm}^{2}\right), \eta_{D C}$ is the efficiency of $\mathrm{DC} / \mathrm{DC}$ voltage regulator, $\xi$ is the ratio between parasitic power and net power consumed by the electrolyzer. [10]

The figure 7 shows PEM electrolyzer efficiency curve for 13,8 bar hydrogen pressure.

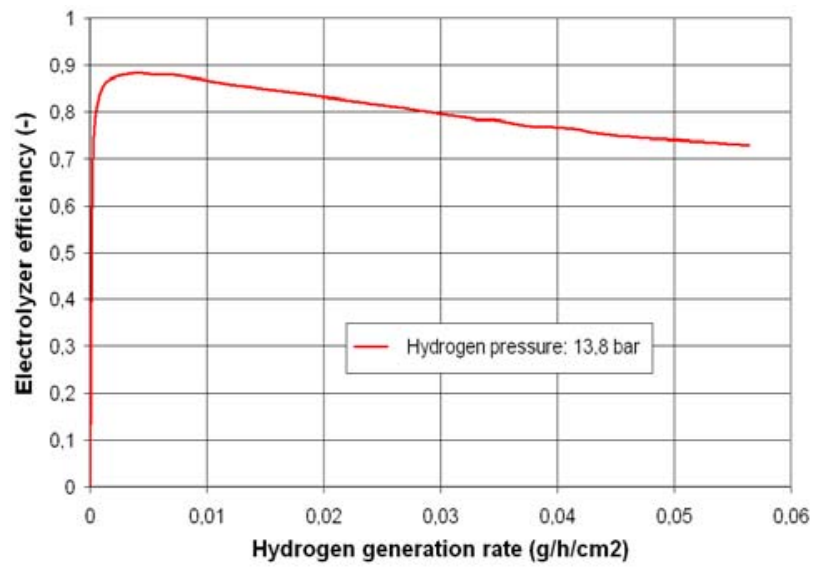

Fig. 7. PEM electrolyzer efficiency

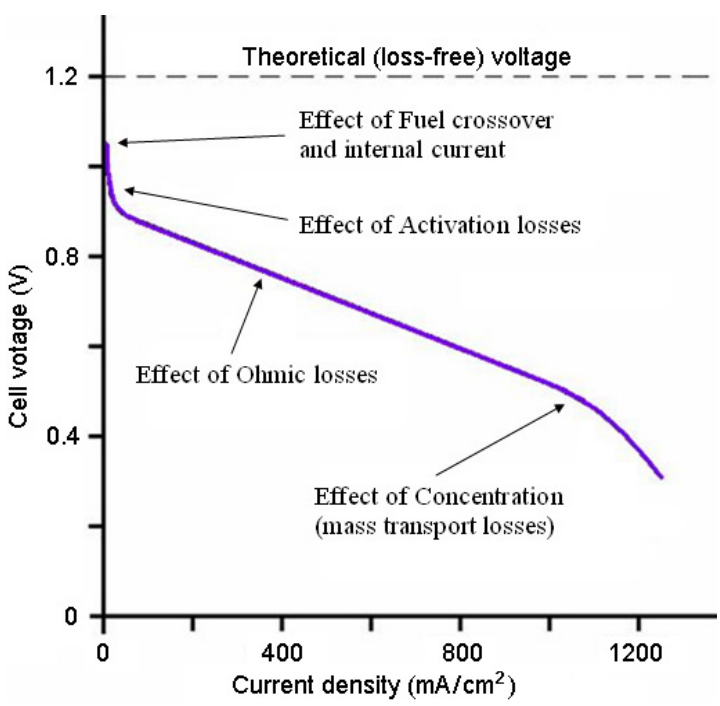

Fig. 8. Voltage-current density characteristic of low temperature fuel cell

\section{B. PEM Fuel Cell}

PEM fuel cell is low-temperature device with polymeric electrolyte membrane (Nafion) able to conduct $\mathrm{H}^{+}$ions from anode towards cathode. PEM fuel cells usually work under temperatures between 50 and $100{ }^{\circ} \mathrm{C}$. Figure 6 shows PEM fuel cells principle. These fuel cells provide for the chemical reaction listed below:

- Anode: $2 \mathrm{H}_{2} \Rightarrow 4 \mathrm{H}^{+}+4 \mathrm{e}^{-}$

- Cathode: $\mathrm{O}_{2}+4 \mathrm{e}^{-}+4 \mathrm{H}^{+} \Rightarrow 2 \mathrm{H}_{2} \mathrm{O}$

- Overall reaction: $2 \mathrm{H}_{2}+\mathrm{O}_{2} \Rightarrow 2 \mathrm{H}_{2} \mathrm{O}$

The fuel cell voltage as a function of current density can be seen in figure 8 . The value of $1,2 \mathrm{~V}$ represents a theoretically loss-free voltage. We can see that the actual cell voltage (incl. the off-load voltage) is always lower than this value. The curve shown in figure 8 is important with respect to efficiency as the rule states the directly proportional relationship between the efficiency and the voltage.

\section{- Fuel Cell Efficiency:}

The efficiency of a fuel cell is usually defined as the actual efficiency of the electro-chemical reaction. This value can be determined as follows: The volume of energy released during the reaction between hydrogen and oxygen to produce water can be described as the Enthalpy of chemical reaction $\left(\Delta H^{\circ}\right)$. This value is measured by means of experiment and it depends on the condition of the resultant product of such reaction, i.e. water, which can be produced either in gaseous or liquid state. As far as fuel cells are concerned, the resultant water will be in gaseous state and the enthalpy of reaction can be calculated using the formula below [11]:

$$
\Delta H_{(\text {gas })}^{\circ}=-242 \frac{\mathrm{kJ}}{\text { mol }_{\text {water }}}=-230 \frac{\mathrm{BTU}}{\mathrm{mol}_{\text {water }}}
$$

where molwater represents $6,023 \cdot 10^{23}$ molecules of water, BTU is the British Thermal Unit (BTU $=1055,0592 \mathrm{~J})$. 


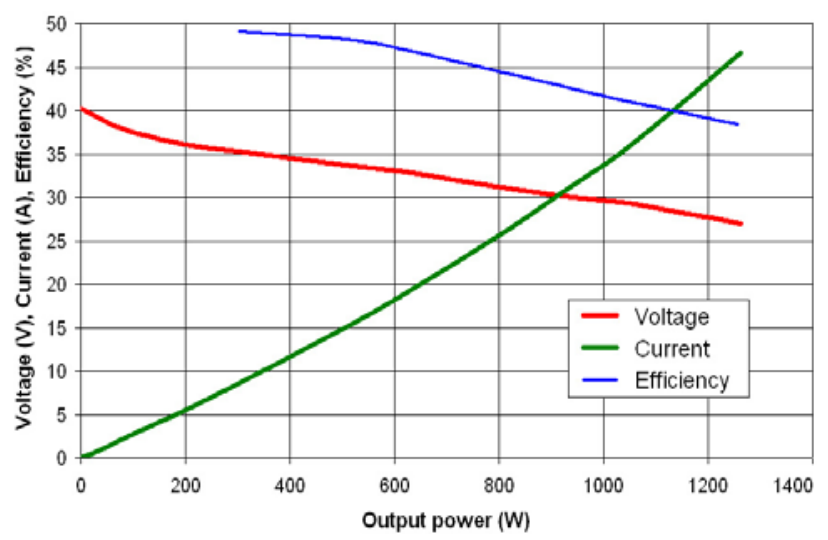

Fig. 9. Load characteristics and efficiency of PEM fuel cells module (Ballard Nexa)

This value of the reaction enthalpy is accurate under laboratory conditions only, with the ambient temperature equal to $25^{\circ} \mathrm{C}\left(77^{\circ} \mathrm{F}\right)$ and the atmospheric pressure of $101,325 \mathrm{kPa}(1 \mathrm{~atm})$. The effect of temperature, as a matter of fact, is then more significant than the pressure level. The magnitude of change related to the volume of energy available will show only minimum changes over the period of PEM fuel cell operation. However, for high temperature fuel cells, the change might reach up to $30 \%$. That is actually the reason, why the efficiency of high temperature cells is lower compared to the low temperature units. [11]

The negative aspect of the reaction within a fuel cell is that the energy released during the reaction would not be absorbed. Therefore the process does not provide for utilisation of the entire volume of energy corresponding to the reaction enthalpy as work. Some of the energy will contribute to the overall chaos in space by means of entropy increase leading to a loss. The remainder of this energy is known as the Gibbs free energy $\left(\Delta G^{\circ}\right)$. As far as water in gaseous state is concerned $\left(25^{\circ} \mathrm{C} ; 101,325 \mathrm{kPa}\right)$, we can use the formula [12]:

$$
\varepsilon_{\text {cell }}=-\frac{\Delta G^{\circ}}{n \cdot F}
$$

where $\varepsilon_{\text {cell }}$ refers to the voltage in every cell related to the Gibbs free energy. Its value can be determined using the formula (3) by means of substitution of relationship between particular units [12]:

$$
\varepsilon_{\text {cell }}=\frac{-229 \mathrm{~kJ}}{\mathrm{~mol}_{\text {water }}} \cdot \frac{1000 \mathrm{~J}}{\mathrm{~kJ}} \cdot \frac{\mathrm{mol}_{\text {water }}}{2 \cdot \mathrm{mol} \mathrm{e}^{-}} \cdot \frac{\mathrm{mol} \mathrm{e}^{-}}{96500 \mathrm{C}}=1,187 \mathrm{~V}
$$

where $n$ refers to the number of electrons involved in the reaction. The most convenient value to show this number is $\mathrm{mol} e^{-}$, where every $\mathrm{mol} e^{-}=6,023 \cdot 10^{23}$ electrons. Bearing in mind the anode and cathode reactions, every molecule of water is formed by two electrons involved. Therefore $n=2 \mathrm{~mol} e^{-}$for every newly formed $\mathrm{mol}_{\text {water }}$. The value of $96500 \mathrm{C} / \mathrm{mol} e^{-}$represents the Faraday's constant.

Each fuel cell can then produce the maximum theoretical voltage of $1,187 \mathrm{~V}\left(25^{\circ} \mathrm{C} ; 101,325 \mathrm{kPa}\right)$. The fuel cell efficiency can be simply shown as the ratio of the actually produced and the theoretically achievable cell voltage [12]:

$$
\eta_{\text {cell }}=\frac{V_{\text {real }}}{\varepsilon_{\text {cell }}} \cong \frac{V_{\text {real }}}{1,187}
$$

The typical voltage in an actual cell is measured at the power load per cell between $0,5 \mathrm{~V}$ and $0,6 \mathrm{~V}$. The off-load voltage reaches the value of $1,1 \mathrm{~V}$. The typical service electrochemical efficiency per cell is approximately between $40 \%$ and $50 \%$. The efficiency reaches the rate of $90 \%$ in case of off-load voltage. [12]

The efficiency versus output power of PEM fuel cellls module is shown in figure 9. The efficiency at full power is approximately $38 \%$. Maximum efficiency is about $50 \%$ and occurs at part load, approximately $300 \mathrm{~W}$. The efficiency quickly declines for part loads less than $300 \mathrm{~W}$, as the auxiliary loads begin to dominate the requirement for hydrogen consumption.

\section{- Load characteristic of fuel cells:}

The measuring procedure consists of measurement of the load characteristics of PEM fuel cells module, whereas the module is connected to the distribution network via inverter, in between these measurements, to supply the electric energy. There are evaluations taken with respect to particular load characteristics together with monitoring of the hydrogen consumption, which is evaluated via measurements of electronic load to obtain more exact values. Electronic load is able to maintain constant power in a long run. The figure 9 shows the load characteristics of PEM fuel cells module (Ballard Nexa).

- Fuel consumption of fuel cells:

The hydrogen consumption of PEM fuel cells module (Ballard Nexa) at various pressures is shown in figure 10 . Hydrogen consumption decreases for raising pressure. The proportion of chemical reaction speed and hydrogen pressure is the reason for this, because the fuel delivery to particular fuel cells is uniform. Higher fuel pressure helps in hydrogen transport to the place of contact with membrane. This pressure sensitivity is the more higher the fuel cells load is higher. [13]

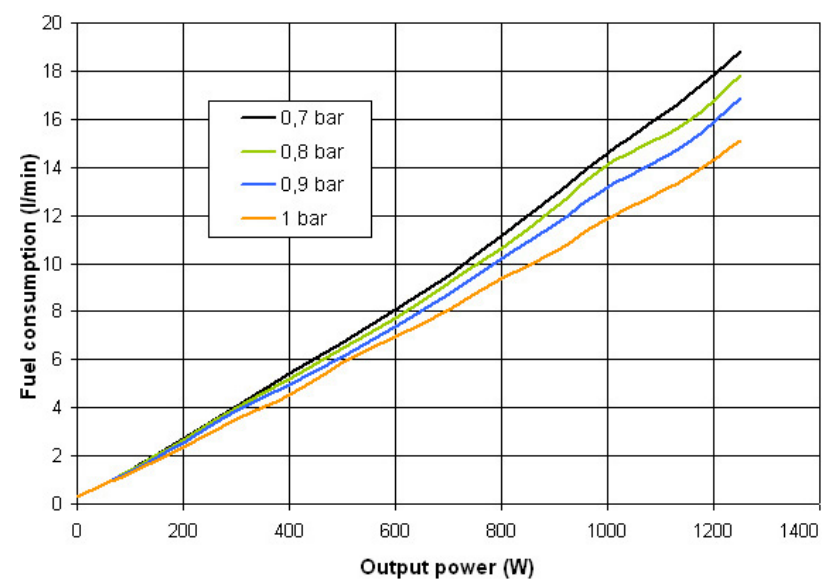

Fig. 10. Fuel (hydrogen) consumption of PEM fuel cells module (Ballard Nexa) 


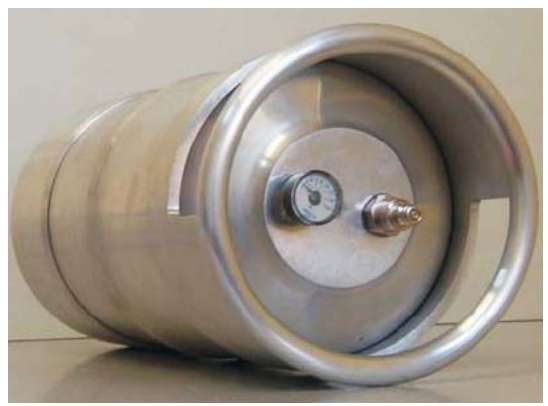

Fig. 11. HBond-1500L metal-hydride bottle

\section{Metal-hydride storage system}

The hydrogen can be stored using various methods. The storage system with metal-hydrides is based on the principle of easy absorption of hydrogen by certain materials under high pressure and moderate temperatures. These substances then release hydrogen, when beating heated under low pressure and relatively high temperatures.

We use metal-hydride bottle for laboratory research. This bottle (HBond-1500L, Labtech Int. Co. Ltd.) is shown in figure 11. It's parameters are shown in Table III.

Desorption PCT (Pressure - Composition - Temperature) isotherms of $\mathrm{La}_{0.85} \mathrm{Ce}_{0.15} \mathrm{Ni}_{5}$ alloy is shown in figure 12. [14]

Table III. - The parameters of HBond-1500L bottle [14]

\begin{tabular}{|l|c|}
\hline Metal-hydride type & $\mathrm{La}_{0.85} \mathrm{Ce}_{0.15} \mathrm{Ni}_{5}$ \\
\hline Hydrogen capacity & $1500 \mathrm{~N}$ liters \\
\hline Charging pressure & 15 bar \\
\hline Charging temperature & max. $25^{\circ} \mathrm{C}$ \\
\hline Discharging pressure & 2 to 7 bar \\
\hline Discharging temperature & $20-40 \mathrm{oC}$ \\
\hline
\end{tabular}

\section{Conclusion}

The energy storage, especially the energy gained from the photovoltaic power plants, is of significant importance with respect to their operation in relation with the electric power system. Those are sources providing variable and unreliable supply of electric power over time, which has negative impact on the operation of the electric power system. The storage of electric energy produced by those units can contribute towards substantial reduction of the control power, which shall be maintained within the electric power system. Storage in hydrogen as an energy carrier is currently the focus of intensive research. It is potentially more effective as a storage medium than other technologies like batteries, especially for use in renewable energy systems. Given the current trend of growth in the installed capacity of photovoltaic power plants, dealing with the issues seems crucial particularly with the future in mind. In addition, using RES systems with energy storage in hydrogen seems very promising as a source of electricity in an island mode. The overall energy transfer efficiency within the hydrogen storage system is one of the important parameters affecting future implementations of this

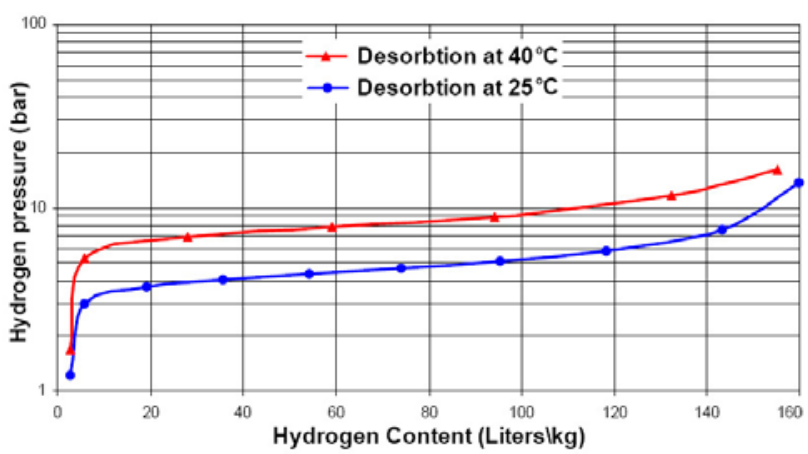

Fig. 12. Desorption PCT isotherms of $\mathrm{La}_{0.85} \mathrm{Ce}_{0.15} \mathrm{Ni}_{5}$ alloy

system. The main objective of our research project of storing the energy from photovoltaics is the optimisation of the entire hydrogen production-to-consumption process so that it works safely, reliably and with high efficiency.

\section{Acknowledgement}

This work was supported by the Ministry of Education, Youth and Sports of the Czech Republic (No. MSM6198910007 and No. CZ.1.05/2.1.00/03.0069).

\section{References}

[1] P. Moldřík, Z. Hradílek, R. Chválek, "Photovoltaic Power Generation", in Proc. PE2010, Vol. 10, pp. 130-135.

[2] R. Chválek, Z. Hradílek, P. Moldřík, "Photovoltaic Sources for Hydrogen Production in the VŠB-Technical University of Ostrava", in Proc. EPE2010, Vol. 11, pp. 407-411.

[3] Z. Hradílek, P. Moldřík, R. Chválek, "Electrical Energy Storage Systems", in Proc. PE2010, Vol. 10, pp. 136-141.

[4] K. Murtinger, J. Beranovský, M. Tomeš, "Photovoltaic: Electricity from the sun", ERA publisher, Brno (2007).

[5] R. Krejcar, "Podpora výroby elektřiny z obnovitelných zdrojů energie z pohledu ERÚ", in Proc. Etherm2010.

[6] R. Chválek, "Photovoltaic sources for hydrogen production in the VSB-Technical University of Ostrava laboratory", in Proc. Wofex2010, Vol. 8, pp. 6-15.

[7] Z. Hradílek, P. Moldřík, R. Chválek, "Storing Solar Energy Using Hydrogen Technology”, in Proc. EEEIC2010, Vol. 9, pp. 110-113.

[8] P. Moldř́k, R. Šebesta, Z. Hradílek, "Research on fuel cells reliability in order to use in accumulation systems of electric energy", in Proc. ESREL2009, Vol. 19, pp. 1671-1675.

[9] Z. Hradílek, P. Moldřík, R. Šebesta, "Accumulation of electric energy using fuel cells and other technologies", in Proc. EPE2009, Vol. 10., pp. 161-166.

[10] F. Barbir, "PEM electrolysis for production of hydrogen from renewable energy sources", Elsevier, Amsterdam (2005), pp. 661-669.

[11] P. Moldř́ik, R. Šebesta, "Hydrogen fuel cells as a part of the system for accumulation of electric energy", in Proc. EPQU2009, Vol. 10., pp. 28-33.

[12] M. Kopřiva, K. Sokanský, "Vliv fyzikálních parametrů palivového plynu na účinnost a kvalitu elektrické energie dodávané PEM palivovým článkem”, in Proc. EPE2005, Vol. 6, pp. 264-278.

[13] R. Šebesta, Z. Hradílek, P. Moldřík, "Research on Fuel Cells in Order to Long Term Use in Storage Systems of Electricity", in Proc. EPE2009, Vol. 10, pp. 88-91.

[14] Hbond 1500L Technical Specification, Labtech Int.Co. Ltd., Bulgaria, 2010. 